\title{
Sharing the corporate tax base: equitable taxing of multinationals and the choice of formulary apportionment
}

\author{
Tommaso Faccio and Valpy Fitzgerald*
}

Tax avoidance by multinational enterprises (MNEs) is a global problem. Most crossborder trade occurs within MNEs, susceptible to abuse of gaps and loopholes in domestic and international tax law that allow "profit shifting" between fiscal jurisdictions in order to reduce corporate tax liability. A lack of transparency makes this kind of tax avoidance difficult to quantify - let alone to monitor and control. This paper provides a case study of profit shifting using publicly available, unique, country-by-country reporting data for Vodafone Group Plc, the first large MNE to voluntarily publish such data. We show the tax impact of a move to formulary apportionment on a global basis, and under the European Union's Common Consolidated Corporate Tax Base proposal. We also consider the rationale for the current proposals for apportionment factors and propose an alternative.

Keywords: transfer pricing, formulary apportionment, CCCTB, developing countries, tax avoidance, horizontal equity, vertical equity, equal distribution, taxing rights

\section{Introduction}

The avoidance of corporation tax by multinational enterprises (MNEs) - essentially on behalf of their shareholders - is facilitated by current international tax rules, based on the separate entity and arm's length principles. MNEs are able to exploit this system to minimise their tax liability, by shifting profits to countries with low or zero tax rates, undermining the tax base of those where real activities take place and reducing government revenues worldwide, in both developed and developing countries.

The scale of this profit shifting to low-tax jurisdictions - known to the International Monetary Fund (IMF) as "conduits" - is very large, involving as much as two-fifths of MNE profits. It has also exacerbated tax competition between countries: the global average statutory corporate tax rate has fallen by more than half over the past three decades (Zucman et al., 2018).

\footnotetext{
* Tommaso Faccio (Tommaso.Faccio@nottingham.ac.uk) is the Head of the Secretariat of the Independent Commission for the Reform of International Corporate Taxation, or ICRICT (www.icrict.com), and Lecturer in Accounting at Nottingham University Business School.

Valpy Fitzgerald (edmund.fitzgerald@qeh.ox.ac.uk) is one of ICRICT's Commissioners and Emeritus Professor of International Development Finance at Oxford University.
} 
Offshore investment hubs also play a major role in global investment. Some 30\% of cross-border corporate investment stocks have been routed through conduit countries before reaching their destination as productive assets, and a logical corollary of the outsized role of offshore hubs in global corporate investments is tax planning (UNCTAD, 2015).

In consequence, G20 world leaders in 2013 gave their support to the Organisation for Economic Cooperation and Development (OECD) project on base erosion and profit shifting (BEPS), calling for reform of the rules to ensure that MNEs would be taxed "where economic activities occur and value is created". ${ }^{1}$ However, the approach taken under the BEPS project ${ }^{2}$ still relies on transfer pricing rules, which start from the independent entity principle and transactional analysis, the so called "arm's length principle". Unfortunately, this principle is extraordinarily difficult to apply objectively in practice.

Alternatives to the arm's length principle do exist (Faccio and Picciotto, 2017) and a logical alternative (ICRICT, 2018) would be to assess multinationals on a worldwide basis (country-by-country reporting, or $\mathrm{CbCR}$ ) and apportion profits (that is, the tax base) by a formula which would allocate a firm's worldwide income across countries, based on allocation factors that reflect real economic activities (e.g. sales, employees, assets). Domestic corporate taxes would be paid on the share of the worldwide income that is allocated to each jurisdiction.

Such apportionment systems do exist, of course, within federal states. Historically, many US states have used the so-called "Massachusetts formula", which uses equal weights on property, payroll and sales, to assess local corporate tax liability from national accounts. Canada employs a similar system, but with equal weights on gross receipts and payroll. Following a similar logic, the European Union (EU) has recently decided to relaunch a project for a Common Consolidated Corporate Tax Base $(\mathrm{CCCTB})^{3}$ based on formulary apportionment, with a decision expected by the end of 2018 .

Initial estimates by the IMF - discussed below - of the effect of such a system, using aggregate data for US firms overseas, indicate that the tax revenue gains would be large for both developed and developing countries, the impact depending on the weights used in the apportionment formula (IMF, 2014). Previous studies using firmlevel data (Clausing and Lahav, 2011; Krchniva, 2014) are based on extrapolation

\footnotetext{
1 http://www.g20.utoronto.ca/2013/2013-0905-tax.html, paragraph 7.

2 http://www.oecd.org/tax/beps/beps-actions.htm.

${ }^{3} \mathrm{https}$ //ec.europa.eu/taxation_customs/business/company-tax/common-consolidated-corporatetax-base-ccctb_en.
} 
from multinationals' financial information available in databases or from financial statements. However, there have been no studies using publicly available CbCR data for multinational firms covering a large number of countries, both developed and developing.

The purpose of this paper is to examine in detail the scale of profit shifting and the effects of apportionment at the firm level, using $\mathrm{CbCR}$ recently published by Vodafone Group Plc. Vodafone is the first multinational group to voluntarily publish $\mathrm{CbCR}$ data, and we hope that its effort to increase transparency by publishing basic financial and qualitative information for each of the countries in which it operates will be followed by other multinational groups. Section 2 explores the tax apportionment issue and establishes three models to be applied to this data. The Vodafone data are presented in Section 3, and the results of the three apportionment models are discussed. Section 4 examines critically the logical basis for these apportionment proposals and sketches a possible alternative based on equity criteria. Section 5 concludes with some implications for future research and policy discussion.

\section{Formulary apportionment}

Tax avoidance by MNEs is a global problem. The greater part of cross-border commerce takes place within MNEs, with an estimated two-thirds of global trade involving related parties (UNCTAD, 2013). This type of trade is susceptible to abusive exploitation of gaps and loopholes in domestic and international tax law that allow for "profit shifting" from country to country, with the intention of reducing the taxes paid on profits. A lack of transparency makes this kind of tax avoidance difficult to quantify, let alone monitor or prevent.

Under the arm's length principle, which underlies separate entity accounting, a multinational corporate group should price transactions with its affiliated entities as if those transactions had occurred with unrelated entities. For tax purposes, affiliated businesses should set transfer prices at levels that would have prevailed had the transactions occurred between unrelated parties.

Multinationals are therefore required to identify market-based prices for goods and services transferred within the multinational, to obtain a price that approximates the result that independent entities would reach in the market.

Transfer pricing rules attempt to construct prices for the transactions among entities that are part of MNEs as if they were independent. This is inconsistent with the economic reality of modern-day MNEs, which are unified firms run by a single management entity and organised to reap the benefits of integration across jurisdictions. This approach requires subjective, ad hoc and discretionary evaluation of each taxpayer by tax authorities in the different jurisdictions in which the taxpayer operates. 
This system also requires significant resources from skilled tax authorities and maintains the incentive for multinationals to create ever more complex group structures to minimise taxes (e.g. investment schemes involving offshore financial centres and special purpose entities) (UNCTAD, 2016).

Profits can be shifted between the affiliates of multinationals in many ways, through the provision of services or sale of goods (multinational groups can manipulate intragroup exports and import prices so that subsidiaries in high-tax countries export goods and services at low prices to related firms in low-tax countries and import from them at high prices; such transfer price manipulations reduce profits in hightax countries and increase them in low-tax countries), through intra-group lending (affiliates in high-tax countries borrow money from affiliates in low-tax countries, which again reduces profits in high-tax countries and increases them in low-tax countries) and the licensing of intangible assets (e.g. proprietary trademarks, logos and patents owned by affiliates in low-tax countries are licensed to other affiliates within the group; these affiliates then receive royalties which reduce profits in hightax countries).

An alternative to the arms-length approach, espoused by the OECD in the BEPS project, would be to tax multinationals under formulary apportionment. Under formulary apportionment, multinationals are treated as a unitary business based on the legal and economic control the parent corporation exercises over its subsidiaries. This unitary business is treated as a single taxpayer, and its income is calculated by subtracting worldwide expenses from worldwide income, based on a global common accounting system. The resulting net income is apportioned among taxing jurisdictions on the basis of a formula that takes into account various agreed factors (e.g. sales, employees). Each jurisdiction then applies its tax rate to the income apportioned to it by the formula and collects the amount of tax resulting from this calculation.

As the global profits of the multinational are distributed across different jurisdictions on the basis of an agreed formula, the multinational would not need to calculate the taxable profits earned by each entity of the group in each jurisdiction. In fact, formulary apportionment is currently adopted in the United States and Canada for the intra-country allocation of the profits of a single entity or a group of entities.

In the experience of US states, income has been allocated to state jurisdictions using a variety of formulas. Historically, many states have used the so-called "Massachusetts formula", which employs equal weights on property, payroll and sales, although, over the years, a significant number of states have moved to a formula that gives more weight to the sales factor (Mintz, 2007). Canada uses equal weights on gross receipts and payroll, with each factor weighted by one-half.

The experience of these countries show that implementation challenges mainly hinge on the apportionment system and the lack of uniformity across states (e.g. 
how the elements of the apportionment formulae are defined) and the lack of consolidation. The importance of gaining agreement among states on a common tax base and common formula is a crucial insight from the experience in the United States and Canada (Weiner, 2005). Despite these challenges, the experience of these two countries provides a useful blueprint for the adoption of this system at the international level.

Under a proposed formulary apportionment system, firms would no longer have an artificial tax incentive to shift income to low-tax locations where their real economic activity is not located. A move to formulary apportionment would also reduce the distortionary features of the current tax system, reducing its complexity and administrative burden.

By ignoring internal arrangements that lead to BEPS, formulary apportionment would enormously simplify international tax rules, ending the need for the complex rules on hybrids, source of income, treaty abuse, and the like. It would also lead to a significant reduction in conflict and uncertainty, by dispensing with ad hoc decisions that require subjective value judgements.

A move to formulary apportionment would also be cost effective and simple for MNEs, as they would need to prepare a global tax return to be submitted to the tax authorities in each of the countries where the multinational operates. There would be an initial setup cost for the appropriate accounting system, but this would be significantly lower than the current cost of implementing, documenting and defending transfer pricing structures under the arm's length approach.

Through formulary apportionment, tax authorities and government would have a better understanding of MNEs' profit allocation across countries. Such a system would also be more suited to an integrated world economy and result in simplification gains and administrative savings.

Although a country could introduce formulary apportionment unilaterally, by requiring MNEs to determine what element of their global profits is taxable in that country, a shift towards formulary apportionment is likely to require coordination to facilitate a move to this system, negotiate an appropriate formula and address some of the associated technical issues (e.g. definition of a common tax base, procedure for consolidation of profits and compliance).

So far, formulary apportionment has been tested only on a country level in a limited number of countries (e.g. the United States and Canada), so a coordinated global move to formulary apportionment would likely be complex, but not more complex than the current system and, in any event, more closely aligned to the economic reality of the modern world. 
The EU has recently decided to relaunch a project for a Common Consolidated Corporate Tax Base (CCCTB) ${ }^{4}$, a single set of rules to calculate companies' taxable profits in the EU based on formulary apportionment. With the CCCTB, cross-border companies would have to only comply with a single EU system for computing their taxable income, rather than many national rulebooks, and would be able to offset losses in one Member State against profits in another. The consolidated taxable profits would be shared between the Member States in which the group is active, using an apportionment formula. Each Member State would then tax its share of the profits at its own national tax rate.

It is to be expected that the redistributive effect of the re-apportionment of the tax base would be considerable, although, as yet, there are no reliable estimates of the scale. Figure 1 summarizes the estimates made by the IMF on the basis of data for US firms operating abroad in 2010 (IMF, 2014). Three elements of the apportionment model are considered separately, each allocated according to its location in the respective tax jurisdiction: sales, payroll and employment. As the Fund points out (2014, p. 38), "These are no more than illustrative, but point to large and systematic effects. Advanced economies generally gain tax base, whichever factor is used, while substantial tax base moves out of conduit countries; emerging and developing economies clearly gain base only if heavy weight is placed on employment."

The category of "conduit" countries as defined by the IMF $(2014$, p. 18) "refers to countries that are widely perceived as attractive intermediate destinations in the routing of investments - whether for tax or other reasons". The IMF (2014) identifies Bermuda, Ireland, Luxemburg, the Netherlands, Singapore and Switzerland as "conduit" countries.

Specifically, as Figure 1 indicates, conduit jurisdictions see large reductions (between 50 and $100 \%$ ) in their tax bases for all four apportionment factors, as would be expected. Further, developed countries experience broadly similar increases in their tax bases under all four factors - of between 30 and 50\%. In other words, as far as these two groups of countries are concerned - and assuming that US firms are representative of all MNEs - the redistributive effect would be robust to the precise apportionment formula used.

The same, however, is not true of developing countries, where each factor (and thus its weight in the formula) has a radically different effect - due essentially to the asymmetrical allocation of these factors between developed and developing countries by MNEs. Specifically, developing countries gain from employment

\footnotetext{
${ }^{4}$ https://ec.europa.eu/taxation_customs/business/company-tax/common-consolidated-corporatetax-base-ccctb_en.
} 
factors and lose from asset factors, as economic theory would predict, due to the lower capital-labour ratios (i.e. technologies) used by firms there as compared with developed countries. The payroll factor actually leads to revenue losses for developing countries because wages are much higher in developed countries. ${ }^{5}$ However, the sales factor seems to benefit developed and developing countries to a similar degree, although in absolute terms the gains are much greater to developed countries, owing to their greater national incomes and thus tax bases. In sum, unlike developed countries, the gains for tax bases in developing countries from the different models of apportionment do depend crucially on the weights given to the factors in the respective formulae.

Absent a comprehensive international database for MNEs similar to that maintained by the US Department of Commerce, an alternative approach to assessing apportionment rules would be to look at individual MNEs. To one such unique case we now turn.

\section{Figure 1. IMF estimate of reallocation of taxable income of US MNEs, using alternative factors (percentage change)}

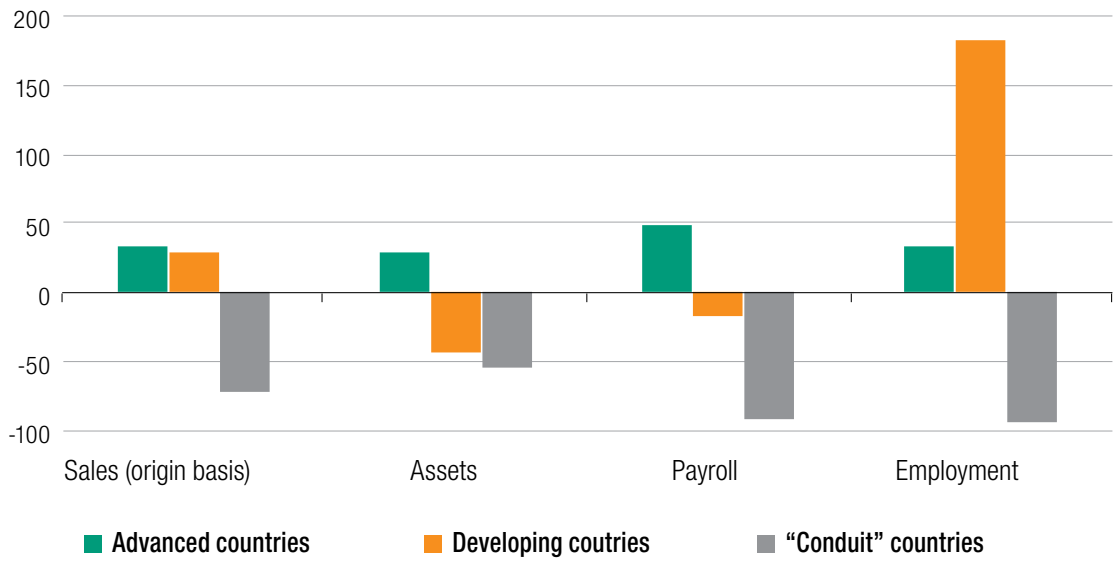

Source: IMF (2014), Appendix VII.

\footnotetext{
${ }^{5}$ Broadly speaking, wage and salary levels are correlated with levels of national income per capita (ILO, 2016).
} 


\section{The Vodafone case study}

Enhancing transparency in the way MNEs report and publish their accounts would help tackle tax avoidance at very low cost. Despite publishing their consolidated accounts as if they are unified entities, MNEs are not taxed in this way. Each business entity within an MNE is taxed individually, making it difficult to establish an overview of what is happening within a group of companies for tax purposes.

This would be different if reporting were done on a country-by-country basis. Public country-by-country reporting $(\mathrm{CbCR})$ is the publication of a defined set of facts and figures by large MNEs, thereby providing the public with a global picture of the taxes that MNEs pay on their corporate income and the allocation of profits across the group's entities. CbCR data is considered to be suitable for high-level transfer pricing risk assessment and for evaluating other BEPS related risks. ${ }^{6}$

Vodafone is the first large multinational ${ }^{7}$ to have voluntarily published countryby-country data, in a report titled Vodafone Group Plc - Taxation and our total economic contribution to public finances 2016-2017.8 The data provided by the Group for 2016-17 (see Appendix to this paper) allows the identification of the sixty countries where the Group operates, the scale of operations in each country, and the allocation of group taxable profits across the different countries in which the Group operates.

Although the data Vodafone supplies fall short of the country-by-country data that MNEs will eventually have to file with tax authorities across the world as part of the OECD CbCR guidelines, ${ }^{9}$ as well as of the EU proposal for a directive on corporate tax transparency country-by-country reporting ${ }^{10}$, and of the data advocated by tax justice campaigners, ${ }^{11}$ these data do finally provide country-by-country information on the revenue and taxable profits, corporate tax payments, employees and assets of the multinational.

A review of the Vodafone report shows that overall taxable profits (profits before tax) for the Group for 2016-17 amounted to $€ 1.9$ billion on revenue of $€ 57.1$ billion, a relatively narrow profit margin of $3 \% .{ }^{12}$ It is unfortunately not possible to calculate

\footnotetext{
${ }^{6}$ OECD Transfer Pricing Guidelines for Multinationals and Tax Administrations, p235.

7 Other than those credit and investment firms (e.g. banks) subject to the requirements of the EU Capital Requirements Directive 4 introduced in 2013 https://eur-lex.europa.eu/LexUriServ/LexUriServ.do?uri= OJ:L:2013:176:0338:0436:EN:PDF.

${ }^{8} \mathrm{https} / / / \mathrm{www}$. vodafone.com/content/dam/sustainability/pdfs/vodafone_2017_tax.pdf.

${ }_{9}^{9} \mathrm{http}: / / \mathrm{www}$.oecd.org/tax/beps/guidance-on-country-by-country-reporting-beps-action-13.htm.

${ }^{10} \mathrm{https}$ ://ec.europa.eu/info/publications/proposal-directive-corporate-tax-transparency-countrycountry-reporting_en.

${ }^{11} \mathrm{https} / /$ www.taxjustice.net/topics/corporate-tax/country-by-country/.

${ }^{12}$ Although it should be recalled that shareholders also benefit from any increase in capital value of the Group.
} 
potential Group tax in the aggregate because liability depends on the tax regime in each jurisdiction and the distribution of the tax base, as well as adjustments from previous years.

The full data base in the Appendix to this paper clearly shows the misalignment between the current taxable profit allocation and indicators of the Group's real economic activities (sales, employees and assets) in the countries where Vodafone operates and thus the potential for BEPS activities by the Group through the use of low-tax "conduit" countries. ${ }^{13}$ Table 1 shows the Group revenue, profit before tax, employment, assets and tax paid for the 10 largest country operations, which accounted for some $70 \%$ of Group activity by sales. We have also calculated the effective tax rate paid (tax paid divided by profit before tax). Data for a single year are not always representative: nonetheless it is notable that six of these 10 country operations reported losses; and one country (Italy) achieved an effective tax rate well below the statutory "headline" rate. In contrast, sales revenue does seem broadly correlated with employment and assets, once the relative capital intensity of developed and developing countries, discussed above, is taken into account.

Table 2, in contrast, shows the top ten Vodafone countries of operations ranked by size of reported profits. The most notable feature is the size of profits reported

\section{Table 1. Vodafone Group countries of operations, top 10 countries ranked by} revenues, 2016-2017 ( $€$ millions)

\begin{tabular}{|c|c|c|c|c|c|c|}
\hline & Country & Revenue & $\begin{array}{l}\text { Profit before } \\
\text { tax }\end{array}$ & Employees & Assets & $\begin{array}{c}\text { Corporation } \\
\text { tax }\end{array}$ \\
\hline 1 & Germany & 10619 & -636 & 15714 & 1925 & 89 \\
\hline 2 & United Kingdom & 7536 & -504 & 17951 & 1491 & -89 \\
\hline 3 & India & 6847 & -338 & 23836 & 1313 & 340 \\
\hline 4 & Italy & 6249 & 686 & 7339 & 881 & 87 \\
\hline 5 & Spain & 4983 & -74 & 5188 & 748 & 0 \\
\hline 6 & South Africa & 4187 & 1077 & 5213 & 544 & 359 \\
\hline 7 & Turkey & 3053 & -59 & 3410 & 336 & 61 \\
\hline 8 & Netherlands & 1867 & -7 & 3601 & 303 & -15 \\
\hline 9 & Egypt & 1334 & 268 & 8381 & 208 & 110 \\
\hline 10 & New Zealand & 1311 & 47 & 2965 & 144 & 19 \\
\hline
\end{tabular}

Source: Appendix.

\footnotetext{
${ }^{13}$ It should be stressed that we are in no way suggesting that Vodafone has engaged in any illegal tax practices.
} 


\begin{tabular}{|c|c|c|c|c|c|c|c|}
\hline & Country & Revenue & $\begin{array}{l}\text { Profit before } \\
\text { tax }\end{array}$ & Employees & Assets & $\begin{array}{l}\text { Corporation } \\
\operatorname{tax}\end{array}$ & $\begin{array}{c}\text { Effective } \\
\text { tax rate (\%) }\end{array}$ \\
\hline 1 & Luxembourg & 187 & 1450 & 325 & 17 & 5 & 0.3 \\
\hline 2 & South Africa & 4187 & 1077 & 5213 & 544 & 359 & 33.3 \\
\hline 3 & Italy & 6249 & 686 & 7339 & 881 & 87 & 12.7 \\
\hline 4 & Kenya & 810 & 293 & 1729 & 126 & 118 & 40.3 \\
\hline 5 & Egypt & 1334 & 268 & 8381 & 208 & 110 & 41.0 \\
\hline 6 & Malta & 86 & 124 & 347 & 14 & 9 & 7.3 \\
\hline 7 & New Zealand & 1311 & 47 & 2965 & 144 & 19 & 40.4 \\
\hline 8 & Romania & 774 & 39 & 4197 & 146 & 6 & 15.4 \\
\hline 9 & Czech Republic & 507 & 32 & 1694 & 92 & 4 & 12.5 \\
\hline 10 & Tanzania & 386 & 29 & 556 & 62 & 23 & 79.3 \\
\hline
\end{tabular}

Source: Appendix.

in Luxembourg, far larger than sales (although these are commensurate with employment), and in Malta, leading inevitably to the hypothesis that these two are the main conduit countries for the Group, with reported profits roughly equal to net profits for the Group as a whole and very low effective tax rates.

In sum, it is clear that considerable profit shifting is occurring within the Vodafone Group - whether for reasons of "tax planning" or "commercial reasons" is unclear but fortunately we do not have to resolve this issue here. However, the data do permit us to see how different models of global formulary apportionment might affect the way the Vodafone tax base is distributed across tax jurisdictions and thus provide a firm-level case study comparable to the aggregate-level IMF study discussed above.

Figure 2 shows how these profits (that is, the corporation tax base) are distributed between regions, based on the World Bank's classification ${ }^{14}$ of low-income, lowermiddle-income, upper-middle-income and high-income countries. This aggregation also helps to smooth out some of the noise inherent in the individual country figures. Vodafone's profits are reported to be $1 \%$ to low-income countries, $14 \%$ to lower-middle-income countries, $27 \%$ to upper-middle-income countries, $19 \%$ to high-income countries and 38\% - the largest share of all - to the "conduit group" of Malta and Luxembourg.

\footnotetext{
${ }^{14} \mathrm{https}: / /$ datahelpdesk.worldbank.org/knowledgebase/articles/906519
} 
Figure 2. Distribution of reported Vodafone profits by region, 2016-2017 (\%)

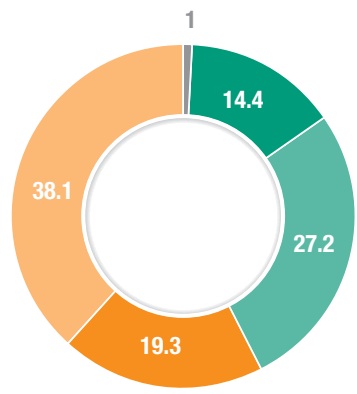

Low-income countries

- Lower-middle income countries

Upper-middle income countries

- High-income countries

Malta and Luxembourg

Source: Appendix.

Our first apportionment exercise is based on equal weighting of sales, assets and payroll, ${ }^{15}$ as an approximation of the US ("Massachusetts") formula (Figure 3). This weighting would decrease the global distribution of Group profits attributable to developing countries (low-income and lower-middle income countries in the World Bank definition) from $15 \%$ to $13 \%$, which would indicate that using a factor that takes into account wage costs may not be beneficial for developing countries.

However, replacing the payroll factor with employment (i.e. number of employees per country) increases the global distribution of Group profits attributable to developing countries, from 15\% to 23\% (Figure 4). In both scenarios, the major gainers would be the developed countries (upper-middle-income and high-income countries), nearly doubling their share, while the conduit group is, of course, the main loser.

Figure 5 shows an apportionment based on sales and number of employees only, equally weighted. The share attributable to developing countries rises slightly compared to Figure 4, at the expense of developed countries, as might be expected - although less so than the IMF estimates discussed above.

\footnotetext{
${ }^{15}$ Unfortunately, no payroll figures are provided in the Vodafone data, only employment figures. However, the International Labour Organisation states that there is a close correlation between national wage/ salary rates and income per capita (ILO, 2016). We have thus used the ratios between income per capita for our four country groups, as given by the World Bank database in 2017 (https://data.worldbank.org/ products/wdi), as a proxy for the earnings ratios, and then applied these to the Vodafone employment data to derive the appropriate apportionment of the 'payroll' element.
} 


\section{Figure 3. Vodafone profit allocation using first formulary apportionment} (equally weighted sales, payroll and assets factors) (\%)

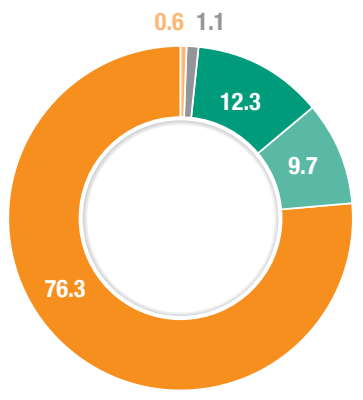

Low-income countries

- Lower-middle income countries

- Upper-middle income countries

High-income countries

Malta and Luxembourg

Source: Appendix.

Figure 4. Vodafone profit allocation using second formulary apportionment (equally weighted sales, employment and assets factors) (\%)

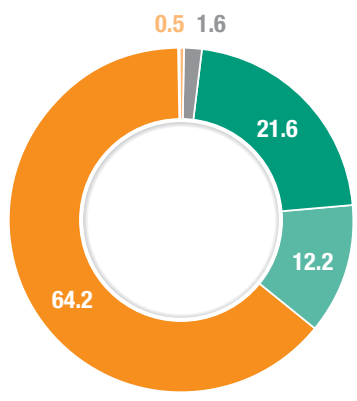

Low-income countries

- Lower-middle income countries

Upper-middle income countries

High-income countries

Malta and Luxembourg

Source: Appendix.

An apportionment based on sales alone, as some would propose, yields the results in Figure 6. This allocation further increases the share of developed countries but at the expense of developing ones.

In sum, the introduction of formulary apportionment does result in a major reassignment of the tax base, mainly to the benefit of developed countries, although developing countries also gain considerably. Although overall it is likely that different apportionment formulae would not fundamentally alter the outcome for developed countries, the impact on developing countries could be significant. 


\section{Figure 5. Vodafone profit allocation using third formulary apportionment} (equally weighted sales and employment factors) (\%)

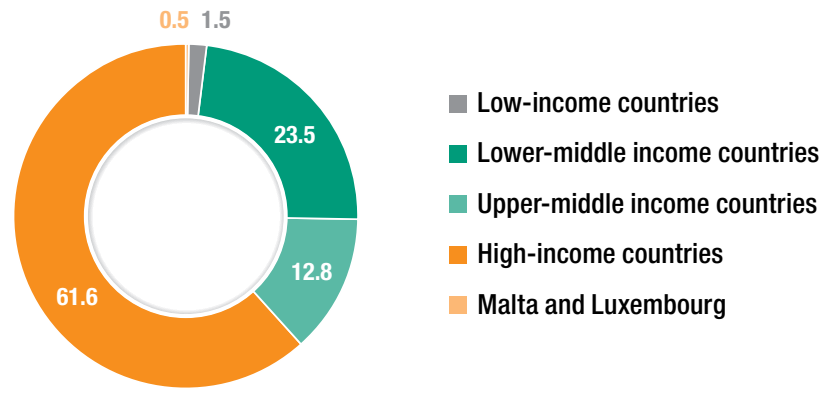

Source: Appendix.

Figure 6. Vodafone profit allocation using fourth formulary apportionment (sales factor only) (\%)

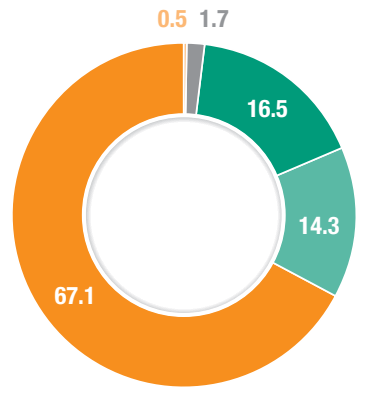

Low-income countries

- Lower-middle income countries

- Upper-middle income countries

High-income countries

Malta and Luxembourg

Source: Appendix.

The data suggest that the use of an employment factor would be likely to result in higher allocation of profits to developing countries, relative to the use of the payroll factor.

Finally, we simulate how the Group profits would be allocated according to the proposed EU CCCTB - sales, employees ${ }^{16}$ and assets equally weighted - between

\footnotetext{
${ }^{16}$ As no payroll data are provided in the CbCR data, and nearly all EU Member States in which the Group operates are high-income countries, no payroll adjustment has been made.
} 
the EU Member States individually. Figure 7 shows that, as expected, the clear losers would be Luxembourg and Malta, which would lose almost all their present Vodafone tax base, as well as Italy. Clear winners would be Germany and the United Kingdom, with significant increases also showing for Spain, the Netherlands and Portugal. The United Kingdom and Germany are Vodafone's top two countries for revenues and are also among their top 10 countries for number of employees, but losses before tax are currently reported for these two countries and this explains why a movement to formulary apportionment would be particularly beneficial to these two countries. The balance of the loss to conduit states would, of course, accrue to the rest of the world - both developed and developing.

Figure 7. Vodafone profit allocation using fourth formulary apportionment (EU CCCTB- difference from current allocation) ( $€$ millions)

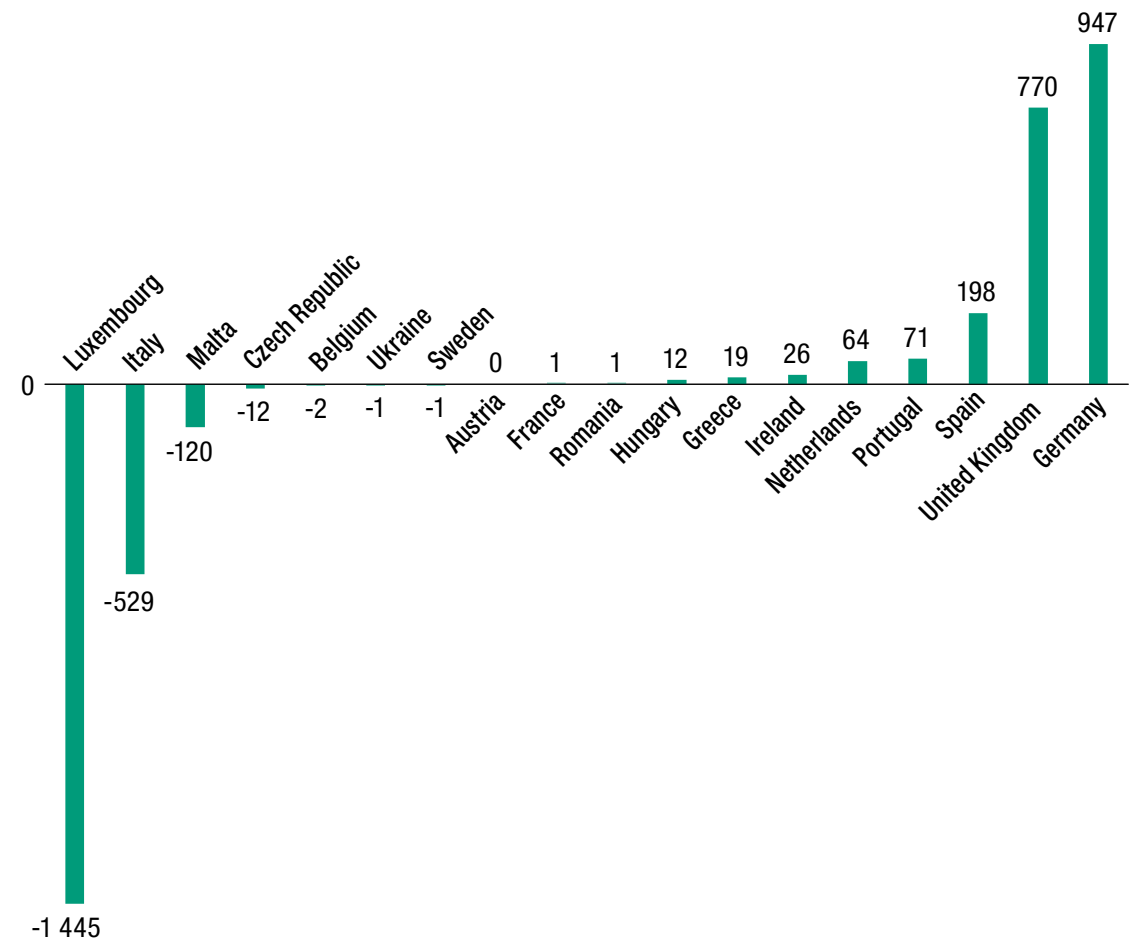




\section{Apportionment and equity issues}

The previous section examined in detail a particular case, although a significant one because Vodafone is a relatively large, global (with CbCR data reported for 49 countries) and technologically advanced MNE. We have shown how profit shifting occurs and what the redistributive effect of various reapportionment formulae would be if applied to this case. The results are interesting and consistent with the IMF study of US MNEs, with the main gainers from reapportionment indicated to be the tax authorities of developed countries, as might be expected; within the EU the main gainers would be Germany and the United Kingdom.

We have taken the factors (sales, assets, employment and payroll) and the formulae (US, Canada and EU) for apportionment from the current international policy framework. Almost inevitably these formulae have emerged from political negotiation over fiscal resources rather than a coherent economic or political theory. Above all, they have emerged within federal polities where there are other redistributive mechanisms, particularly the allocation of the resources generated by corporate taxation. There is no reason therefore why such formulae should be best for an international non-federal system other than that these formulae form a useful precedent for negotiating.

The three canonical criteria for judging taxation are "equity, efficiency and ease". ${ }^{17}$ As the staff of the US Congress states:

Analysts generally apply three principal economic criteria when judging the merits of any tax system: Does that tax system increase or decrease equity across taxpayers? Does it increase or decrease economic efficiency (that is, the extent to which market decisions are free of distortions introduced by the tax)? And can that tax system be easily administered? (JCT, 2008, p. 48)

"Ease" refers to administrative feasibility and cost on the one hand, and transparency on the other. It is clear that formulary apportionment in any form is superior in "ease" to the present system of conflicting jurisdictions, and that, by effectively eliminating conduits, it would raise tax revenue without great administrative cost because MNE groups already prepare CbCR for their internal use.

"Efficiency" in the sense of reducing market distortions is clearly achieved by any formulary apportionment because it would eliminate the enormous present complexity and distortions created by tax avoidance schemes and the use of artificial conduits.

\footnotetext{
${ }^{17}$ See, for instance, Meade (1976).
} 
There is less clarity about the first criterion, that of "Equity". Internationally (and indeed between federal states) this concept in the present context relates not so much to individual taxpayers but rather to equity in distribution between tax jurisdictions. This of course is the rationale behind the three formulae discussed above, which aim to achieve a more equitable distribution of tax base (and thus revenue) between countries.

The somewhat scarce policy literature on the subject appears to be based on a concept of taxing profits "where economic activities occur and value is created". The OECD intergovernmental agreements on BEPS refer to the need for the tax base to "reflect the underlying economic reality"18 without explicitly stating how this is to be defined; while the Independent Commission on the Reform of International Corporate Taxation states that

"... these factors, such as employment, sales, resources used, fixed assets, etc., should be chosen to reflect the MNE's real economic activity in each jurisdiction" (page 6) and that "It is the Commission view that global formulary apportionment is the only method that allocates profits in a balanced way using factors reflecting both supply (e.g., assets, employees, resources used) and demand (sales). Neither can create value without the other." (ICRICT, 2018, p. 7)

However, while such an approach to the creation of "value" has some appeal in terms of political economy, there is little economic theory to underpin it. The so-called "Massachusetts Formula" apparently has become accepted through precedent (i.e. political negotiation between states) rather than as the result of economic analysis or research into the impact. A line of argument might be derived from the "contribution of factors of production" approach with, say, the location of "land", "labour" and "capital"; but this would exclude sales and extend the definition of assets.

Moreover, from a textbook standpoint, profits are attributable to capital alone because the other factors are rewarded according to their marginal productivity; and, of course, in the standard neoclassical model (with no scale economies), profits are the marginal productivity of capital itself plus the reward to entrepreneurship. On this basis, apportionment should be based on the true location of real fixed capital, technology and management or entrepreneurship.

In neither approach does sales come into the economic argument. The case for including sales seems to be based more on ease of administration than anything else. However, the attraction of this case is that it ultimately implies replacing direct with indirect taxation - which in turn has undesirable consequences for equity (IMF,

\footnotetext{
${ }^{18} \mathrm{http}$ ://www.oecd.org/ctp/beps-frequentlyaskedquestions.htm.
} 
2013). Corporation tax is, in essence, a withholding tax on dividends and is thus strongly progressive, reducing income inequality; sales taxes on the other hand are usually regressive.

Moreover, the "value creation" approach seems to misunderstand the fact that large firms' profits arise from market power (including intellectual property and the like) and specifically from their multinational nature - or to put it another way, these are spatially unlocated rents that should be taxed. As Avi-Yonah and Clausing (2007, p. 13) explain:

multinational firms exist in large part because these interactions generate more income than would separate domestic firms interacting at armslength; thus requiring firms to allocate this additional income among domestic tax bases is necessarily artificial and arbitrary, because it would by definition disappear if the related entities operated at arm's length.

Finally, assessment of the distributive effects of different apportionment schemes should take into account not only the direct impact on different countries' revenues but also the response of companies to the new rules. For instance, a company could sub-contract its labour inputs in any one jurisdiction and thus could shift its tax liability under formulary apportionment. What this illustrates is the problem of effectively assessing value chains that stretch across sectors and countries, where effective control may be exercised not only by ownership but also by contracts, technology, franchising and other means.

In addition, we have already seen how apportionment systems would necessarily benefit developed countries most (at the expense of conduit countries, some of them developing countries) because this is where most sales, capital and high wages are to be found.

There is a case therefore for examining what other criteria might be used to underpin the formula for international apportionment. Here we will briefly sketch just one ${ }^{19}$ in outline, the application of an apportionment principle of equity between countries that is based on income per capita.

When designing personal income taxation it is conventional to include an element of progressivity on the grounds of the greater "ability to pay" of richer strata of the population - or in economic terms, the declining marginal utility of money with income. This is normally called "vertical equity" in contrast to "horizontal

\footnotetext{
${ }^{19}$ There are other possibilities, of course. For instance, apportionment might be linked to the need to finance global public goods, and thus involve some fraction being allocated directly to global funds for the environment, epidemics, natural disasters and so on. Again, to the extent that corporation tax can be seen as a 'service charge' for the use of national public facilities, apportionment might reflect the extent of these facilities.
} 
equity", which ensures that taxpayers at similar income levels pay similar amounts, independently of the source of income.

By extension, we could argue that current apportionment proposals are mainly concerned with horizontal equity between jurisdictions, but that, logically, an element of vertical equity should also be introduced. In other words, the apportionment weights should be based on - or at least include - the level of per capita national income, to ensure a more equal distribution of taxing rights (i.e. how the multinational's tax base is shared between developed and developing countries).

This may appear to be a radical proposal, but it does have indirect precedents. On the one hand, within federal polities (upon which the current formulae are based) there does exist - implicitly - a strong redistributive element insofar as federal direct taxation is "returned" in the form of fiscal transfers on a notionally per capita basis. On the other, the current system of international development cooperation ("aid") is essentially fiscal, involving the raising of taxation in the donor country and the support of public expenditure ${ }^{20}$ in the recipient country.

A somewhat more conventional form of this proposal would parallel the special provisions in trade agreements for less developed participants. In terms of formulary apportionment this could take the form of an agreed adjustment factor for the three developing-country groupings discussed in the previous section.

A move to formulary apportionment, either based on existing apportionment formulae or on our proposal would have effect both on the tax revenue generated and investment decisions by MNEs.

Whilst taxation is only one of the factors on which investment decisions are based, in addition to eliminate opportunities for base erosion and profit shifting, a system of formulary apportionment could remove the inherent subjectivity of the current system of international tax rules thereby providing greater economic certainty to taxpayers and governments, and this should in turn encourage cross-border investment.

The risk of double taxation in the current system is high, with multiple countries asserting taxing rights on the same tax base. However, under a system of formulary apportionment investors will be able to predict in advance of the investment decision the effective rates at which each country will impose its tax, therefore increasing tax certainty.

\footnotetext{
${ }^{20}$ Most expenditure by international non-governmental organizations in developing countries is fiscally funded too, and although 'privately spent' is usually in support of or a replacement for provision of public welfare.
} 


\section{Conclusion}

The analytical and empirical evidence in this paper shows that a move to formulary apportionment is likely to minimise the allocation of MNEs' profits to low-tax jurisdictions, where multinationals have limited economic activities. The profits currently allocated to these jurisdictions would be reallocated to both developed and developing countries.

Research on this subject has been constrained by the lack of firm-level data. However, the results from a detailed examination in this paper of the CbCR data of Vodafone Group Plc, the first large multinational to voluntarily publish such data, allow us to demonstrate the profit-shifting process and to estimate the effect of formulary apportionment for a major MNE based in the United Kingdom, which supports the aggregate analysis of US corporations overseas by the IMF.

We also suggest that the current formula proposals are limited by a lack of clear economic rationale, on the one hand, and insufficient attention to the equitable treatment of developing countries, on the other.

The policy implications of this paper are four. First, clearly much more research covering a longer time period is needed at the firm level. Ideally this would be comprehensive, but if not possible then a representative selection should be made of MNEs in distinct sectors and based in distinct countries. In particular, MNEs based outside the US and EU (particularly those from emerging-market economies) should be well covered.

Second, policy debate should move on from the need for formulary apportionment to the nature of the formula and participation in its determination, with particular attention to low-income countries. There appears to be some current momentum towards basing apportionment on sales, driven in good part by concerns about e-commerce, but this may not be helpful to developing countries.

Third, although formulary apportionment does not require a global body to collect or redistribute tax, it does require a multilateral forum where rules can be established, methodology approved and disputes arbitrated. These rules would cover not only the apportionment formula as such but also the reconciliation of national and regional differences in accounting criteria and tax expensing. Whether the OECD (which has already made progress on these topics) or the UN (which has representational legitimacy) should be the locus for such an initiative is an open question.

Fourth, a clear linkage should be established between debates on international taxation and other global debates on income inequality, sustainable development and multilateral institutions. Fiscal coordination is not just an issue of financing for development but rather one of the bases for global economic cooperation as such. In these debates, developing countries should have both voice and vote. 


\section{References}

Avi-Yonah, R. S., and Clausing, K. A. (2007). A Proposal to Adopt Formulary Apportionment for Corporate Income Taxation: The Hamilton Project. University of Michigan Public Law Working Paper No. 85.

Clausing, K. A., and Lahav, Y. (2011). Corporate tax payments under formulary apportionment: Evidence from the financial reports of 50 major U.S. multinational firms. Journal of International Accounting, Auditing and Taxation 20(2), pp. 97-105.

Faccio, T., and Picciotto, S. (2017). Alternatives to the Separate Entity/Arm's Length Principle for Taxation of Multinational Enterprises [online] available at: https://www.icrict.com/ resources/icrict-documents.

ICRICT (2018). A roadmap to improve rules for taxing multinationals. A fairer future for global taxation. [online] available at: https://www.icrict.com/resources/icrict-documents.

ILO (2016). Global Wage Report 2016/17 Geneva: International Labour Organization, [online], available at: https://www.ilo.org/global/research/global-reports/global-wagereport/2016/lang--en/index.htm.

IMF (2013). Fiscal Monitor 2013. DataMapper, [online], available at: https://www.imf.org/en/ Publications/FM/Issues/2016/12/31/Taxing-Times.

IMF (2014). Spillovers in International Corporate Taxation. IMF Policy Paper, [online] available at: https://www.imf.org/external/np/pp/eng/2014/050914.pdf.

JCT (2008). A Reconsideration of Tax Expenditure Analysis Prepared by the Staff of the Joint Committee on Taxation. JCX-37-08, US Congress, Washington, DC.

Krchniva, K. (2014). Comparison of European, Canadian and U.S. formula apportionment on real data. Procedia Economics and Finance 12, pp. 309-318.

Meade, J.E. (1978). The Structure and Reform of Direct Taxation: Report of a Committee Chaired by Professor James. E. Meade. London: Allen and Unwin, London.

Mintz, J., (2007). Europe Slowly Lurches to a Common Consolidated Corporate Tax Base: Issues at Stake. In Lang, M., et al., A Common Consolidated Corporate Tax Base for Europe. Berlin, Heidelberg: Springer.

UNCTAD (2013). Global Value Chains: Investment and Trade for Development. World Investment Report 2013. New York and Geneva: United Nations, p. 136.

UNCTAD (2015). Reforming International Investment Governance. World Investment Report 2015. New York and Geneva: United Nations, pp. 188-190.

UNCTAD (2016). Investor Nationality: Policy Challenges. World Investment Report 2016. New York and Geneva: United Nations, p. 150. 
Weiner, J. M. (2005). Formulary Apportionment and Group Taxation in the European Union: Insights from the United States and Canada. Taxation Papers, WP no.8.

Zucman, G., Tørsløv, T., and Ludvig, W. (2018). The Missing Profits of Nations. NBER Working Paper No. 24701. 


\section{Appendix}

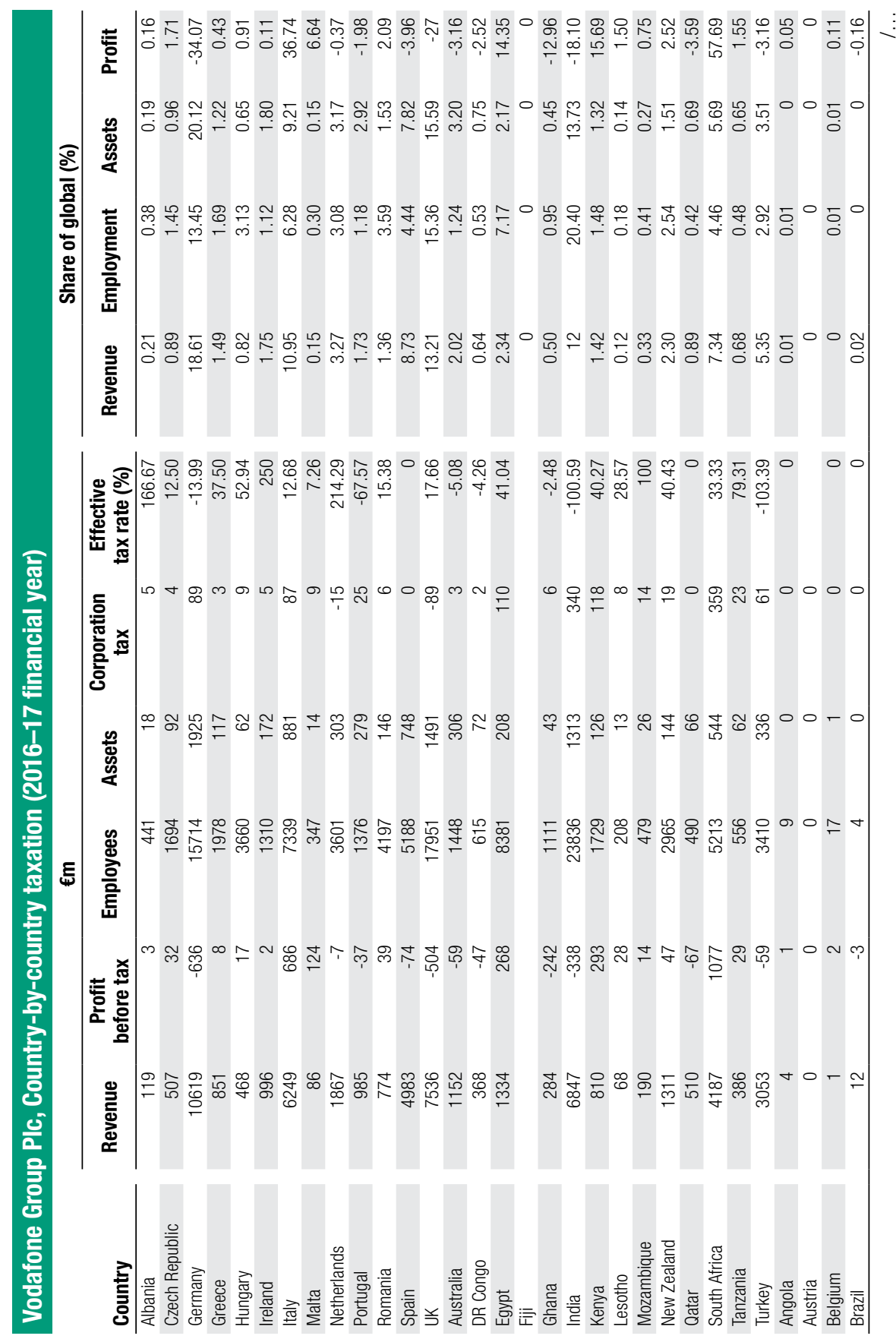




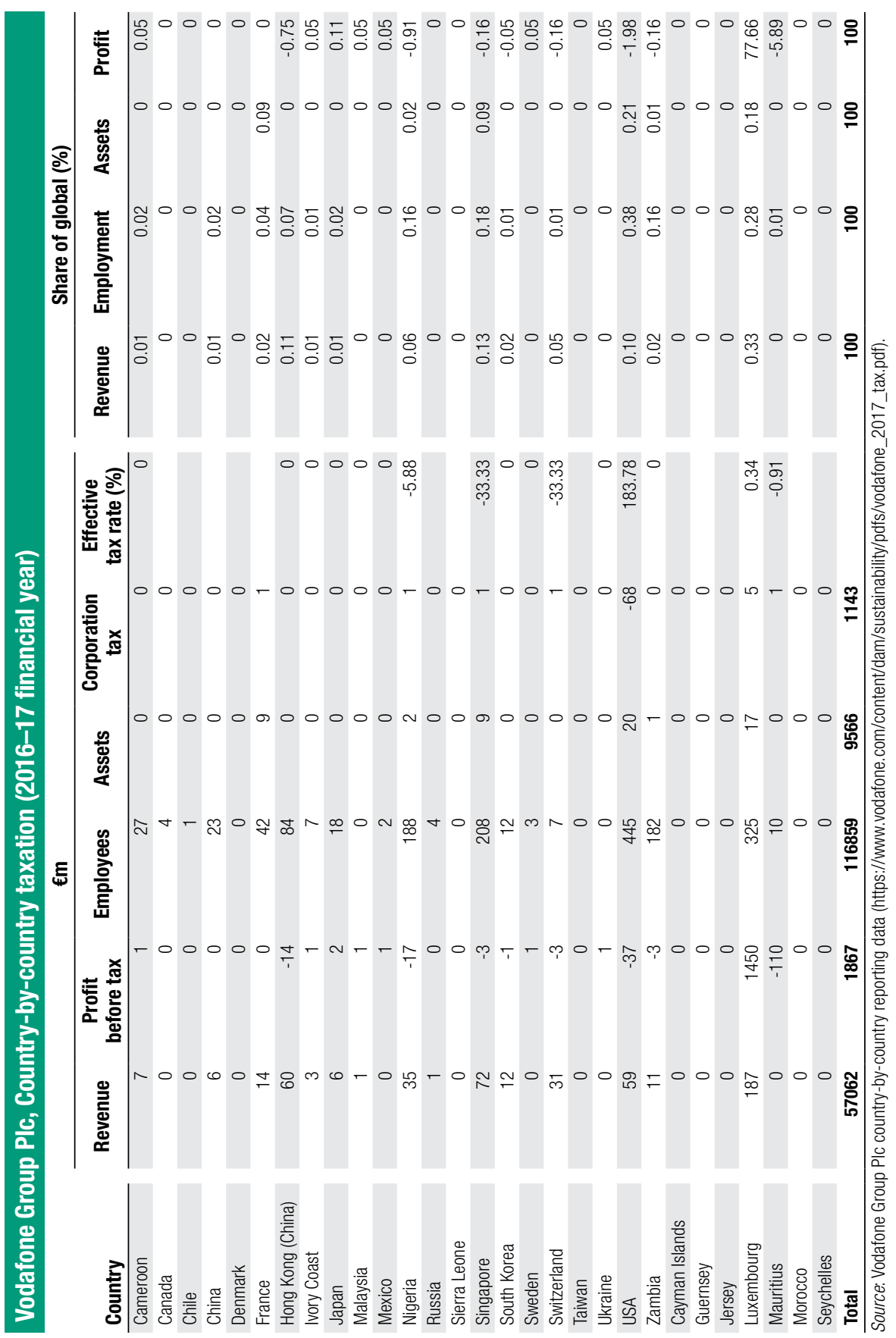


